BJHS 53(1): 67-88, March 2020. C The Author 2020. This is an Open Access article, distributed under the terms of the Creative Commons Attribution licence (http://creativecommons.org/licenses/ by/4.0/), which permits unrestricted re-use, distribution, and reproduction in any medium, provided the original work is properly cited.

doi:10.1017/S0007087419000906 First published online 14 January 2020

\title{
Optimizing and normalizing the population through hormone therapies in Italian science, c. $1926-1950$
}

\author{
CHIARA BECCALOSSI*
}

\begin{abstract}
This essay explores how hormone treatments were used to optimize and normalize individuals under Italian Fascism. It does so by taking the activities of the Biotypological Orthogenetic Institute - an Italian eugenics and endocrinological centre founded by Nicola Pende in 1926 - as the prime example of a version of eugenics, biotypology, which was based on hormone therapies. This essay first demonstrates that Italian Fascist biopolitics was not only concerned with increasing the size of the Italian population, but also with improving its quality. It suggests that under the Italian Fascist regime hormone therapies became eugenic tools of intervention to improve the Italian race. Second, while Pende's institute purportedly enhanced men and women, its activities show the extent to which the 'techniques of normalization' pursued by the Fascist regime were both systematic and invasive.
\end{abstract}

The attempt to optimize the bodies of men and women - as opposed to the mere treatment of illness and disease - was one of the defining characteristics of twentieth-century biopolitics. ${ }^{1}$ Governments, in collaboration with medical doctors, promoted and implemented a wide range of policies to enhance the individual's body and the general population, from specific therapies and regimens of personal hygiene to public-health campaigns and eugenics programmes. One of the best-known and most extreme historical examples of biopolitical intervention is provided by Nazi Germany, with its programmes of birth control, compulsory sterilization and euthanasia of the 'racially unfit'. ${ }^{2}$ The Italian case - or at least the practical application of biopolitics under the Fascist regime - is, however, less familiar. ${ }^{3}$ While the Italian Fascist regime pursued

* University of Lincoln, Brayford Pool, Lincoln, LN6 7TS, UK. Email: CBeccalossi@lincoln.ac.uk.

This study was supported by the Wellcome Trust (Ref: 108687/Z/15/Z). I would like to thank Peter Cryle and the anonymous peer reviewers for their comments on a previous version of this article. Any remaining mistakes are my own.

1 Nikolas Rose, The Politics of Life Itself: Biomedicine, Power, and Subjectivity in the Twenty-First Century, Princeton, NJ: Princeton University Press, 2007.

2 Edward Ross Dickinson, 'Biopolitics, fascism, democracy: reflections on our discourse concerning “modernity", Central European History (2004) 37, pp. 1-48.

3 Most of the literature on Pende simply refers to eugenics. See, for example, Claudio Pogliano, 'Scienza e stirpe: Eugenica in Italia (1912-1939)', Passato e presente (1984) 5, pp. 61-97; Carl Ipsen, Dictating Demography: The Problem of Population in Fascist Italy, Cambridge: Cambridge University Press, 1996; 
pro-natalist policies, it also systematically sought to improve the population in terms of biology, genetics and psychology. ${ }^{4}$ It aspired to optimize individual bodies, as propaganda regarding the creation of the 'New Man' indicates. ${ }^{5}$

One of the most significant, and at the same time overlooked, Italian examples of scientific intervention to improve the 'race' is the use of hormone treatments. ${ }^{6}$ Regarded until very recently as a somewhat esoteric topic, the history of hormones has begun to attract attention from scholars in a number of different fields, the history of science and queer studies among them. As the philosopher Paul B. Preciado has argued, without a historical account of the manipulation of hormones, contemporary sexual politics cannot be fully understood. The investigation and use of so-called 'sex hormones' have been pivotal in the management of reproduction, in the invention of sexual difference as 'anatomical truth', and in the development of techniques for the normalization of the body and gender production. ${ }^{7}$

In this Italian case study, hormone research went hand in hand with eugenic politics: hormone treatments became eugenic tools, compatible with Catholic values by virtue of their constituting a post-natal intervention. Yet they could also be invasive. The history of how eugenics and hormone research were intertwined in Italy reveals another important feature. Hormone therapies were used not only to enhance Italians, but also to normalize them. Michel Foucault has indicated that 'normalization' became one of the fundamental disciplinary technologies of modern biopolitical institutions, which operated both at the level of the general population and on the individual's body. ${ }^{8}$ Thus the history of how scientists in the interwar period employed hormone therapies for eugenic purposes can be seen as an example of the technologies of normalization that Foucault has brought to light and, at the same time, may contribute to our understanding of contemporary sexual politics. ${ }^{9}$

A prime example of how hormone therapies were employed to optimize and normalize the population is provided by the Biotypological Orthogenetic Institute, established in

Roberto Maiocchi, Scienza italiana e razzismo fascista, Florence: La Nuova Italia, 1999; Claudia Mantovani, Rigenerare la società: L'eugenetica in Italia dalle origini Ottocentesche agli anni Trenta, Soveria Mannelli: Rubettino, 2004; Francesco Cassata, Molti, sani, forti: L'eugenetica in Italia, Turin: Bollati Bolinghieri, 2006.

4 Maria Sophia Quine, Population Politics in Twentieth-Century Europe: Fascist Dictatorships and Liberal Democracies, London: Routledge, 1996. Historical accounts generally accept that Nazi Germany eugenics programmes aimed to improve the quality of the people, while Italian Fascist eugenics programmes aimed to boost numbers.

5 On the 'New Man' see Emilio Gentile, L'apocalisse della modernità: La Grande Guerra per l'uomo nuovo, Milan: Mondadori, 2008.

6 Many Italian eugenicists believed there was no single Italian race, but a number of Italian races. See Aaron Gillette, Racial Theories in Fascist Italy, London: Routledge, 2002. For the sake of simplicity I will refer in this essay to a single Italian race.

7 Paul B. Preciado, Testo Junkie: Sex, Drugs, and Biopolitics in the Pharmacopornographic Era, New York: The Feminist Press, 2013 (first published 2008).

8 Michel Foucault, Discipline and Punish: The Birth of Prison, London: Penguin, 1978 (first published 1975); Foucault, The History of Sexuality, vol. 1: An Introduction, London: Penguin, 2008 (first published 1976).

9 For a history of the concept of normality and techniques of normalization see Peter Cryle and Elizabeth Stephens, Normality: A Critical Genealogy, Chicago: The University of Chicago Press, 2017. 
1926 by Nicola Pende. Regarded as one of the most important exponents of the so-called 'Latin eugenics' and the founder of biotypology, Pende was also a pioneer in the field of endocrinology, and recognized as such by the international medical community. ${ }^{10} \mathrm{On}$ three separate occasions Pende was nominated for a Nobel Prize in Physiology or Medicine in recognition of his major contributions to the field of endocrinology. ${ }^{11} \mathrm{His}$ important treatise, Endocrinologia (Endocrinology), was first published in 1914, went through several editions (each of which was enlarged), and was widely read, especially by scientists who spoke Romance languages. ${ }^{12}$

By focusing on Pende's Biotypological Orthogenetic Institute and the use of hormone treatments to optimize the human body, this article first demonstrates that during Fascism, Italian biopolitics was not only concerned to boost the population, but also to improve the quality of the 'Italian stock'. Under the Italian Fascist regime hormone therapies became eugenic tools of intervention to ameliorate the Italian 'race'. The basic assumption behind hormone use was that the body was malleable and that changes caused by hormone treatments could be transmitted to offspring. Second, while Pende's institute purportedly enhanced men and women, its activities show the extent to which the 'techniques of normalization' carried out during the Fascist regime were pervasive, invasive and tangible.

\section{Nicola Pende and the Biotypological Orthogenetic Institute}

Modern hormone treatments, one could argue, began in Europe with rejuvenation therapies. In 1889, the seventy-two-year-old French physiologist Charles-Edouard BrownSéquard reported that he had injected into himself testicular extracts from dogs and guinea pigs. ${ }^{13}$ His colleagues and the medical press were sceptical about the effects of

10 Nancy Leys Stepan, The Hour of Eugenics: Race, Gender and Nation in Latin America, Ithaca, NY: Cornell University Press, 1991; Cassata, op. cit. (3); Marius Turda and Aaron Gillette, Latin Eugenics in Comparative Perspective, London: Bloomsbury, 2014.

11 In 1937 for his work on endocrinology; in 1943 for his work on the biotypology of man, surgical treatment of essential hypertension and hyperfunction of the thymus; in 1951 for his work on endocrinology. According to Maria Sophia Quine, Pende himself coined the term 'endocrinology' in 1909. Maria-Sophia Quine, 'Racial "sterility" and "hyperfecundity" in fascist Italy: the biological politics of sex and reproduction', Journal of Comparative Fascist Studies (2012) 1(2), pp. 92-144, 113.

12 Compare Nicola Pende, Endocrinologia: Patologia clinica e organi a secrezione interna, Milan: F. Vallardi 1914; and Pende, Endocrinologia patologica e clinica degli organi a secrezione interna, Milan: Società Editrice Libraria, 1949. For a useful survey of Pende's contribution to endocrinology see Giorgio Cosmacini, Medicina e sanità in Italia nel ventesimo secolo: Dalla 'Spagnola' alla Guerra Mondiale, Rome: Laterza, 1989, pp. 160-165. On Pende and constitutional medicine see Giorgio Cosmacini, 'Scienza e ideologia nella medicina del Novecento: dalla scienza egemone alla scienza ancillare', in Franco della Peruta (ed.), Storia d'Italia, Annali 7: Malattia e medicina, Turin: Einaudi, 1984, pp. 1223-1267.

13 Official histories of endocrinology go back to the mid-nineteenth century when the French physiologist Claude Bernard coined the term 'internal secretion' and when German physicians like Arnold Berthold, when experimenting on animals, showed that testes and ovaries discharged a chemical substance affecting other parts of the male and female body. See, for example, C. Sengoopta, The Most Secret Quintessence of Life: Sex, Glands, and Hormones, 1850-1950, Chicago: The University of Chicago Press, 2006, p. 4; and E.S. Watkins, The Estrogen Elixir: A History of Hormone Replacement Therapy in America, Baltimore: Johns Hopkins University Press, 2007, p. 12. 
testicular extracts, but so-called organotherapy or opotherapy became a fin de siècle remedy for a number of different disorders, from fatigue and sexual impotence to period pain and infertility. ${ }^{14}$ It also inspired serious experimental research on glandular functions. ${ }^{15}$ Glandular extracts, usually collected in slaughterhouses, became increasingly employed as experimental therapeutic resources. For example, in the 1890s, animal pancreas and thyroid gland extract injections were tested at University College London in an attempt to treat diabetes and myxoedema, and in Durham, George Murray started to experiment with sheep thyroid implants to treat diabetes in humans. ${ }^{16}$

At the beginning of the twentieth century, a growing number of endocrinologists became interested in manipulating the so-called 'sex hormones'. In Vienna, Eugen Steinach, director of the Physiological Section of the Institute of Experimental Biology from 1912, began experimenting with sexual development in rats and guinea pigs. Steinach and his team realized that the 'internal secretions' produced by testes and ovaries could alter secondary sexual characteristics and even animals' behaviour. Male castrated animals acquired typically female secondary sexual characteristics if ovary extracts were administered, and female castrated animals acquired typically male secondary sexual characteristics if administered testes extracts. Even behavioural patterns such as mating or suckling would change. Moving from the laboratory to the clinic and from animals to humans, Steinach advanced two controversial clinical treatments: 'rejuvenation', particularly in frail, elderly millionaires, and treatments for male homosexuality. ${ }^{17}$ But perhaps the most notorious doctor to have experimented with sex glands and hormones at the beginning of the twentieth century was the French Russian surgeon Serge Voronoff, who implanted ape testicles ('monkey glands') into ageing men. ${ }^{18}$

Between the 1920s and 1930s opotherapy became highly popular in medical circles throughout Europe, the US and Latin America, being used to treat a number of different conditions. ${ }^{19}$ Rejuvenation therapy in particular attracted a great deal of attention. Prominent men of science such as Sigmund Freud underwent rejuvenation therapies, while novelists made it a popular topic. For example, the American author Gertrude Atherton, who had sought glandular treatment for her writer's block, wrote about opotherapy in her work Black Oxen (1923). By the early 1920s, hormone research

14 Organotherapy, or opotherapy, made use of various extracts from the endocrine glands of animals, not only testes and ovaries. The thyroid gland was also commonly used and, in some cases, so too were other animals' organs such as the heart or the lungs.

15 Chandak Sengoopta, 'Dr Steinach coming to make old young! Sex glands, vasectomy and the quest for rejuvenation in the roaring twenties', Endeavour (2003) 27(3), pp. 122-126.

16 Christer Nordlund, Hormones of Life: Endocrinology, the Pharmaceutical Industry, and the Dream of a Remedy for Sterility, 1930-1970, Sagamore Beach: Science History Publications, 2011, p. 25; Victor Cornelius Medvei, A History of Endocrinology, Lancaster: International Medical Publishers, 1982, pp. 159-194.

17 Sengoopta, op. cit. (15), p. 123.

18 David Hamilton, The Monkey Gland Affair, London: Chatto \& Windus, 1986; Sengoopta, op. cit. (13), pp. 94-99.

19 Diana Long Hall and Thomas F. Glick, 'Endocrinology: a brief introduction', Journal of the History of Biology (1976) 9(2), pp. 229-233; Michael Petitt, 'Becoming glandular: endocrinology, culture, and experimental lives in the interwar age', American Historical Review (2013) 118(4), pp. 1052-1076; Sengoopta, op. cit. (13). 
had become so important in many Western countries that scientists assigned to hormones the same sort of powerful meaning as DNA has today; scientists believed that once they had learnt how to manipulate these molecules, they would be able to treat a wide variety of diseases through appropriate hormone therapies.

In Pende's Biotypological Orthogenetic Institute, the use of hormones to treat a wide range of endocrinological dysfunctions and conditions came from the experimental medical tradition that Brown-Séquard had initiated, but at the same time it took a new direction, being associated with the attempt to enhance the Italian population at large. As Christer Nordlund has pointed out, in the first half of the twentieth century there were three approaches to eugenics: the first, so-called negative eugenics, sought to prevent undesirable individuals from being born; the second, so-called positive eugenics, aimed to produce individuals with better-than-average characteristics; the 'third way', namely hormone therapy, was designed to remake, improve and refine the human material that was already at hand. ${ }^{20}$ Pende's work can be interpreted as a part of this last trend, a point borne out by the testimony of internationally renowned interwar scientists who assigned to his institute the role of pioneer in optimizing the human body. This is well illustrated by Alexis Carrel, the French biologist, surgeon and Nobel Prize laureate in Medicine or Physiology who, in his classic eugenic text L'homme, cet inconnu (Man, the Unknown) (1935), lavished praise on Pende and his Italian Biotypological Orthogenetic Institute. It was, he declared, a world-leading institution, one responsible for pioneering a new medical trend:

In Genoa Nicola Pende has established an institute for the physical, moral and intellectual enhancement of the individual. Many people are beginning to feel the necessity for a broader understanding of man. However, this feeling has by no means been formulated as clearly here [in the US] as in Italy. ${ }^{21}$

Thus the fame of Pende's Biotypological Orthogenetic Institute, often simply known as the Institute of Biotypology, was due not to its research into disease cures, as we might expect from a medical centre, but to its supposed capacity to enhance the individual and control every aspect of human existence, even the most intimate.

Carrel's words testify to the high regard in which Pende was held in international scientific circles during the interwar period. However, as Pende's research and activities might well be obscure to historians unfamiliar with the Italian history of science, clarifying terms such 'orthogenesis' and giving a brief description of Pende's professional and cultural background are necessary. Orthogenesis was a branch of constitutional medicine that dealt with issues related to individual growth; that is, with the bodily and psychological development of men and women. ${ }^{22}$ Advocates of constitutional

20 Christer Nordlund, 'Endocrinology and expectations in 1930s America: Louis Berman's ideas on new creations in human beings', BJHS (2007) 40(1), pp. 83-104, 100.

21 Alexis Carrel, L’homme, cet inconnu, Paris: Librairie Plon, 1935, p. 350. All translations into English are mine, unless stated.

22 On constitutional medicine see, for example, Carsten Timmermann, 'Constitutional medicine, neoromanticism, and the politics of antimechianism in interwar Germany', Bulletin of the History of Medicine (2001) 75(4), pp. 717-739. On constitutional medicine and sexual taxonomies see April Trask, 
medicine emphasized the importance of 'predisposition' as a cause of disease, the primacy of a clinical approach favouring an individualized and holistic notion of illness and presupposing an indissoluble relationship between mind and body. ${ }^{23}$ They developed a plethora of taxonomies that associated different body types with different personalities and predispositions to certain diseases and abnormalities. In Italy, constitutional medicine thrived, its success being due in part to the country's humanistic and Catholic culture, traditionally hostile as it was to materialistic reductionism. ${ }^{24} \mathrm{By}$ ascribing to the mind a central role, constitutional medicine seemed to offer a perspective more aligned with Catholic sensibilities, which, of course, emphasized the spiritual component of man. At the beginning of his medical career, Pende was influenced by constitutional medicine and soon became the most important scientist to promote 'constitutionalism' in the Fascist period. He graduated with a medical degree in 1903 with a thesis involving experimentation on kittens, in which he demonstrated the relationship between the endocrine glands and the nervous system. ${ }^{25}$ After being employed in various hospitals in Rome, in 1909 he began working for Giacinto Viola, one of the most influential advocates of constitutional medicine. Under Viola, Pende held the position of medical assistant, first at the Special Medical Pathology Cabinet within the University of Palermo and then in Bologna from 1919.26

\section{The invention of biotypology}

Between 1921 and 1924, Pende published the first explicit elaboration of biotypology, in which its potential uses to enhance the individual and the Italian population became apparent. In Dalla medicina alla sociologia (From Medicine to Sociology) (1921), he expounded the theory according to which the endocrine glands, especially the thyroid, the adrenal and the sexual glands, due to their links with the vegetative nervous system, have an impact upon an individual's constitution-meaning not only the body, but also intellectual and moral development. Therefore, according to Pende, the endocrine glands affect human psychology, the emotional sphere, and even sexual behaviour. ${ }^{27}$ But the actual appearance of the term 'biotypology' came one year later

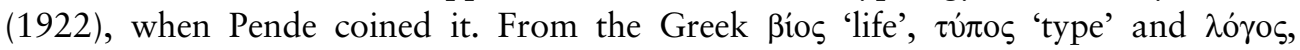

'Remaking men: masculinity, homosexuality and constitutional medicine in Germany, 1914-1933', German History (2018) 36(2), pp. 181-206.

23 Sellina Gualco and Antonio Nardi, L'istituto Biotiplogico Ortogenetico di Roma, Rome: Proja, 1941, pp. 15-16. See also Sarah W. Tracy, 'An evolving science of man: the transformation and demise of American constitutional medicine, 1920-1950', in Cristopher Lawrence and George Weisz (eds.), Greater than the Parts: Holism in Biomedicine, 1920-1950, New York: Oxford University Press, 1998, pp. 161-188.

24 Mantovani, op. cit. (3), p. 226.

25 Tommaso Dell'Era, 'Strategie politiche ed esigenze scientifiche: il ruolo di Nicola Pende nell'istituzione e nell'organizzazione dell'Università di Bari', Annali di storia delle università italiane (2013) 17, pp. 45-67, 47.

26 Dell'Era, op. cit. (25), p. 48. In the meantime, Pende had visited Berlin in 1914 and then served as an army doctor during the First World War. Emmanuel Betta, 'Nicola Pende', Dizionario biografico degli Italiani, at www.treccani.it/enciclopedia/nicola-pende_\%28Dizionario-Biografico\%29.

27 Dell'Era, op. cit. (25), pp. 52-53. 
meaning word, study or doctrine, Pende defined biotypology as the science 'of the architecture and engineering of the individual human body'. ${ }^{28}$

This new science drew on Viola's study of 'constitutional types', but used endocrinology to classify individuals: the distinct biotypes were thus identified on the basis of the different levels of hormone production by the various endocrine glands in different human constitutions. ${ }^{29}$ In Pende's work the biotype (or constitution) was the synthesis of individual, family and racial heredity; the morphological habitus, including racial characteristics; temperament in relation to the individual's endocrinology (or hormonal balance) and blood physical chemistry; the affective sphere and will power (that is, the personality); and individual intelligence and attitudes. ${ }^{30}$

Biotypology was a clinical approach that was designed to treat not the sick, but the healthy, and to reveal their morbid hereditary or acquired predispositions. It aimed to identify and correct bodily anomalies, preferably before the individual reached adulthood. Biotypology drew attention to minor weaknesses and sought to reveal the relationship between the endocrine and the nervous systems, as it was believed that early interventions were more successful than those implemented later. ${ }^{31}$ This did not mean that Pende's biotypology was not used to treat the sick, since in his clinical practice Pende did indeed treat people suffering from endocrine disorders. The essential aim of biotypology, however, was to improve the physical, psychological and sexual development of individuals so that 'normality' could be ensured and abnormalities prevented. In this system, whereby bodily anomalies indicated morbid predispositions, biotypologists used hormone treatments to prevent disorders whenever possible, or else to treat them. Pende judged that the endocrinal glands were specific sites for neo-Lamarckian action: changes in the individual's milieu could impact upon the endocrine glands, which would then secrete hormones; these in turn would alter the sex cells, and eventually these changes might be transmitted to offspring. Thus hormone therapies could correct the unbalanced functioning of the endocrine glands and transmit such corrections to future generations. Enhancing the individual through hormone treatments ultimately meant improving the Italian population. In this sense, hormone treatments were eugenic tools of intervention.

It was Pende himself who, in a self-congratulatory vein, stated that he had coined the term 'biotypology' in 1922, the same year Mussolini had marched on Rome with his Fascist blackshirts ${ }^{32}$ - a telling circumstance, revealing that Pende's scientific ascent and his increasing involvement with Fascism were intertwined from the very start of

28 N. Pende, Trattato di biotipologia umana individuale e sociale con applicazione alla medicina preventive, alla clinica, alla politica biologica, alla sociologia, Milan: Vallardi, 1939, p. 1.

29 On Pende's early career and biotypology see Dell'Era, op. cit. (25). For his influence outside Italy see Stepan, op. cit. (10).

30 'Morphological habitus': meaning the physique, the physical and constitutional characteristics of an individual, especially as related to the tendency to develop a certain disease. A morphological habitus might, for example, be a relatively short and powerfully built body, or a relatively long and thin one, and so on. On Pende's concept of biotype see Emilio Maura and Paolo F. Peloso, 'Allevatori di uomini: Il caso dell'Istituto biotipologico ortogenetico di Genova', Rivista sperimentaledi freniatria (2009) 133(1), pp. 10-35, 24.

31 Maura and Peloso, op. cit. (30), p. 24.

32 Pende, op. cit. (28), p. 1; Quine, op. cit. (11), pp. 114-115. 
his career. In 1924 he enrolled in the Partito Nazionale Fascista (PNF - National Fascist Party) and in 1928 he became director of the Fascist youth organization Opera Nazionale Balilla (ONB) for the Liguria region. ${ }^{33}$ His various works contained more or less explicit apologias for Fascism and his Bonifica umana razionale e biologia politica (Human Rational Reclamation and Political Biology) (1933) was actually dedicated to Mussolini. ${ }^{34}$ Finally, Pende's political career was crowned by his appointment as senator by King Vittorio Emanuele III in 1933. ${ }^{35}$ Pende's work also achieved national renown thanks to Mussolini's patronage, but beyond merely opportunistic reasons for supporting the Fascist regime, such as the possibility of more readily obtaining funding for his own institute, Pende saw in Mussolini's government an opportunity to put into practice the social-medical programmes that liberal governments had not been able to guarantee. ${ }^{36}$ Furthermore, Pende shared with Mussolini's Fascist regime the totalitarian aspiration to control each and every aspect of everyday life, even the most intimate, from what Italians ate to the ways in which they had sex; all with the explicit aim of improving the Italian stock. As a number of historians have pointed out, Pende did indeed contribute to Mussolini's eugenics ambition to strengthen the Italian population through his work aimed at the biopolitical control of the individual. ${ }^{37}$ However, the system of interventions used by Pende to improve the population differed from that typical of Northern European countries and perhaps of the better-known variants of eugenics. Aligning himself with Catholic precepts, Pende believed that eugenics should not be carried out through birth control, or through the sterilization of people, but only through the 'medical normalization of the human body and mind'. ${ }^{38}$ Rejecting prenatal intervention, Pende had created a variant, or a 'third way', of eugenics, based on hormone treatments which 'corrected' individuals in the early stages of their life. In his writings, he openly distanced himself from what historians call negative eugenics; orthogenesis, Pende emphasized, should not be confused with eugenics as practised in countries such as Germany because it was a postnatal intervention. ${ }^{39}$ Instead of the term 'eugenics' he preferred to use the term 'biotypology' or 'orthogenetic biotypology' to refer to his own eugenicist beliefs and practices. ${ }^{40}$

33 Maura and Peloso, op. cit. (30), p. 30.

34 Nicola Pende, Scienza dell'ortogenesi, Bergamo: Istituto Italiano d'Arti Grafiche, 1939; Pende, op. cit. (28); anon., 'Scritti e conferenze di Nicola Pende', in Archivio Centrale di Stato, Ministero della Pubblica Istruzione, Direzione Generale, Professori Universitari Epurati, 1944-46, p. 26, Nicola Pende. Nicola Pende, Bonifica Umana Razionale e Biologia Politica, Bologna: Cappelli, 1933.

35 For a short biography of Pende see Betta, op. cit. (26).

36 Dall'Era, op. cit. (25), p. 56.

37 Pogliano, op. cit. (3); Ipsen, op. cit. (3); Maiocchi, op. cit. (3); Mantovani, op. cit. (3); Cassata, op. cit. (3).

38 The original Italian reads as follows: 'la normalizazzione medica della fabbrica umana fisica e psichica'. Gualco and Nardi, op. cit. (23), pp. 159-160.

39 Pende, Scienza dell'ortogenesi, op. cit. (34), p. 8. His collaborators said, 'Pende's general principle, is that eugenics [eugenesi]' cannot be practised through birth control, contraceptive prophylaxis, or spouses' sterilization, but with the 'human bodily and psychical medical normalization'. In Gualco and Nardi, op. cit. (23), pp. 159-160.

40 Pende's collaborators refer to biotypology as a form of eugenics. See Gualco and Nardi, op. cit. (23), pp. 159-160. 


\section{The Biotypological Orthogenetic Institute}

Pende's programme of normalization of the Italians was fully implemented in his Biotypological Orthogenetic Institute. When, in 1925, Pende replaced the celebrated Italian doctor Edoardo Maragliano as director of the medical clinic at the University of Genoa, he was at long last able to break free of his mentor Viola, and to promote and apply his own version of constitutional medicine, biotypology. ${ }^{41}$ One year after his arrival in Genoa, on 19 December 1926, Pende launched the Biotypological Orthogenetic Institute in the presence of the minister of education, Professor Pietro Fedele, who had been personally invited. ${ }^{42}$ The institute was part of the University of Genoa and was a state institution; its personnel were therefore paid by the central government. ${ }^{43}$ The institute in Genoa was established with the 'cooperation' of Fedele, as the same minister wrote, and its opening was approved by Mussolini. ${ }^{44}$ The institute's purpose was to screen the health and ethnic composition of the entire Italian population, in addition to the already mentioned aim of rectifying bodily anomalies and improving the Italian stock.

According to the French journal La presse médicale, which had lavished praise on Pende's institute, by 1930 there were already thirty 'collaborators' working at the institute in addition to Pende. ${ }^{45}$ It is possible, however, that this number included students who were training there, as in 1933 Mario Barbara, doctor and deputy director of the institute, and Giuseppe Vidoni, a psychiatrist who worked with Pende at the institute in Genoa, reported that the institute consisted of Pende, twelve other medical researchers, a technical photographer, a technician responsible for the upkeep of the scientific and medical equipment, and a librarian. ${ }^{46}$ The institute in Genoa was divided into five departments or sections. The morphological and endocrinological department studied the individual endocrine temperament, examined the endocrine glands and tested the chemical reactions of the secretions of the glands. The psycho-pedagogic department examined people's psychological attitudes. The work orientation department tested the professional aptitudes of young people and advised them, functioning in practice

41 Gualco and Nardi, op. cit. (23), pp. 48-50, 57-67.

42 Archivio Centrale di Stato, PCM, 1927, Fasc. 5. 1. 688, letter from Nicola Pende to Benito Mussolini, 16 December 1926.

43 Anon., 'L'Istituto Biotipologico-Ortogenetico di Genova', Riforma medica (24 January 1927) 42(4), pp. 103-105. At this date the Italian healthcare system was still poorly regulated, and patients paid a fee when entering a hospital unless they were poor, in which case local authorities paid the pauper's fee. See Domenico Preti, 'La questione ospedaliera nell'Italia fascista (1922-1940): un aspetto della "modernizzazione corporativa", in Franco Della Peruta (ed.), Storia d'Italia, Annali 7: Malattia e medicina, Turin: Einaudi, 1984, pp. 335-390.

44 Archivio Centrale di Stato, PCM, 1927, Fasc. 5. 1. 688, letter from the dean of the University of Genoa, Mattia Moresco to Benito Mussolini, 16 November 1926 (Genoa), and letter from Pietro Fedele to Benito Mussolini, 11 February 1927.

45 Marcel Martiny, 'La biotypologie humaine et orthogénésique: Sa première application clinique et medico-sociale', extract from La presse médicale (8 October 1930) 81, p. 12, in Archivio Centrale di Stato, Segreteria Particolare del Duce, Carteggio Ordinario, 1922-43, Busta 1001, Fasc. 509057/509059.

46 Mario Barbara and Giuseppe Vidoni, L'Istituto Biotipologico Ortogenetico di Genova, Genoa: Carlo Badiali \& C., 1933, pp. 21-33. For an overview of this institute based on Vidoni and Barbara's work see also Mauro and Peloso, op. cit. (30). 
as an occupational medicine department. The researchers in the experimental genetics department studied the growth processes of the human being, and the intra- and extra-uterine development and hereditary functions of men and women. Finally, the 'physical orthogenetic department' focused on sports education and aimed to correct bodily and moral anomalies. ${ }^{47}$ In the description of the institute in Genoa provided by Barbara and Vidoni, each department consisted of a number of rooms devoted to every kind of examination: from anthropometric to functional and blood tests, with all individuals being photographed, and the results of the examinations likewise recorded. ${ }^{48}$ The morphological and endocrinological department was devoted to hormone research 'applied to the clinic', where researchers conducted hormone tests on patients; administered various forms of radiation therapy to stimulate hormone production; and conducted experimental hormone therapies on children, men and women, and experimental research on animals. ${ }^{49}$

In 1935, Pende obtained the prestigious chair of special medical pathology at the University of Rome, and the minister of the public education made official the transfer of the Biotypological Orthogenetic Institute to Rome on 1 January $1936 .{ }^{50}$ Initially, the new institute was located within the University of Rome and was funded by the Ministry of Public Education, as the one in Genoa had been. But the ONB, and the Opera Nazionale della Madre e dell'Infanzia (OMNI - National Organisation for the Protection of Motherhood and Childhood) also contributed financially to the running of the institute in Rome. ${ }^{51}$ When Pende applied to the government for financial backing for the Roman institute, he emphasized that one of the principal functions of his institute was the enhancement of the Italian 'race'. As he explained to the government, the Roman institute would consist of three main departments: physiology, clinic and orthogenetic therapy for adolescents; physiology, clinic and constitutional therapy for adults; and finally 'race biology and racial reclamation' ('biologia della razza e bonifica raziale'). ${ }^{52}$ In practice, the structure of the departments at the Roman institute was similar to that in Genoa. ${ }^{53}$ The Roman institute's ultimate goal, however, was to regenerate the Italian 'race' (or 'races'), and its fundamental aim - to help Mussolini create the

47 Martiny, op. cit. (45), pp. 10-11. According to other authors the focus of the five departments was slightly different. See also Gualco and Nardi, op. cit. (23), pp. 13-15. The departments' focus changed over time. I report the description by Martiny because, in my view, it is one of the earliest and the most detailed.

48 Barbara and Vidoni, op. cit. (46), pp. 21-33.

49 Barbara and Vidoni, op. cit. (46), pp. 33-34.

50 The chairs were in patologia speciale medica in 1935 and in patologia special medica e metodologia clinica; see Ministero dell'educazione nazionale, Stato di Servizio di Nicola Pende, 30/152, Archivio Centrale di Stato, Ministero della Pubblica Istruzione, Direzione Generale, Professori Universitari Epurati, 1944-46, b. 26, Nicola Pende. About the transferral of the institute to Rome see Gualco and Nardi, op. cit. (23), p. 9.

51 Gualco and Nardi, op. cit. (23), p. 9; Archivio Centrale di Stato, Presidenza del Consiglio dei Ministri, 1934-36, Fascicolo 5.1. no. 2766, Letter 5.12.XIII, 1933; and Presidenza del Consiglio dei Ministri, 1934-36, Fascicolo 5.1. no. 2766.

52 Archivio Centrale di Stato, Presidenza del Consiglio dei Ministri, 1934-36, Fascicolo 5.1, no. 2766.

53 Gualco and Nardi, op. cit. (23). See also Francesco Cassata, 'Biotypology and eugenics in Fascist Italy', in Matthew Feldman, Jorge Dagnino and Paul Stocker (eds.), The 'New Man' in Radical Right Ideology and Practice, 1919-45, London: Bloomsbury, 2018, pp. 39-63. 
'New Man' - became ever more firmly entrenched as time passed. Writing at the time about the Roman institute, Sellina Gualco and Antonio Nardi, two of Pende's closest collaborators who worked with him in both Genoa and Rome, said that Pende himself identified the institute as Mussoliniano in its very nature, serving as it did to 'defend our people'. This aim, they said, was achieved through the 'physical and spiritual' training of Italian children and the mothers of the future, the promotion of hygiene and the medical prevention of disease and the consequent boost to the productivity of workers, and the enhancement of the integrity of the Italian stock by means of the eradication of hereditary diseases. ${ }^{54}$ The Roman institute, Gualco and Nardi continued, saw to the 'integrity, prevention, normalization and correction of thousands and thousands of individuals.' 55 While Pende's collaborators always referred to the institute as the Biotypological Orthogenetic Institute, in Pende's own correspondence with the government he called it the Human Reclamation and Racial Orthogenesis Institute ('Istituto di Bonifica Umana e Ortogenesi della Razza), 56 and in his book Scienza dell'ortogenesi (The Science of Orthogenesis), published in 1939, he referred to the institute as the Fascist Institute of Human Reclamation and Orthogenesis (Istituto Fascista di Bonifica Umana e Ortogenesi). ${ }^{57}$

From 1926, when Pende established the Biotypological Orthogenetic Institute in Genoa, to 1943, when Italian Fascism fell, the institute was strategically placed at the service of Mussolini himself, who approved, lent his backing to, and showed an interest in its activities. To symbolically cement this alliance, Mussolini laid the foundation stone when construction of a new building for the Biotypological Orthogenetic Institute started in the current EUR (Esposizione Universale Roma) area in March $1938 .{ }^{58} \mathrm{It}$ was at this time that the official name of the institute became Institute for Human Reclamation and Racial Orthogenesis (Istituto di Bonifica Umana ed Ortogenesi della Razza). ${ }^{59}$ The official opening of the new and massive building was scheduled for the end of 1940 (Figure 1). ${ }^{60}$ There is no space here to scrutinize in detail the historical evolution of Pende's institute, but suffice it to say that the institute continued to operate until at least the early 1960s, despite Pende being relieved of his academic post after the fall of Fascism. ${ }^{61}$ The name was, of course, altered after the Second World War, when it became known as the Endocrinological Institute.

Through a national system of 'orthogenetic clinics' (ambulatori ortogenetici), which the next section will cover, a large proportion of the people who ended up at the institute

54 Gualco and Nardi, op. cit. (23), p. 12.

55 Gualco and Nardi, op. cit. (23), p. 149.

56 Archivio Centrale di Stato, Presidenza del Consiglio dei Ministri, 1937-39, Fascicolo 14.2.6770.

57 Pende, Scienza dell'ortogenesi, op. cit. (34), p. 222.

58 Archivio Centrale di Stato, PCM 1937-39, Fascicolo 14.2.6770.

59 Archivio Centrale di Stato, PCM 1937-39, Fascicolo 14.2.6770. Roma, Cerimonia Posa la Prima Pietra dell'Istituto di Bonifica Umana ed Ortogenesi della Razza, 23 March 1939.

60 Archivio Centrale di Stato, PCM 1937-39, Fascicolo14.2.6770. Roma, Cerimonia Posa la Prima Pietra dell'Istituto di Bonifica Umana ed Ortogenesi della Razza, 23 March 1939, and letter, 1 November 1939.

61 Archivio Centrale di Stato, Presidenza del Consiglio dei Ministri, Gabinetto, 1951-54, Fascicolo 5-1, no. 83001. 


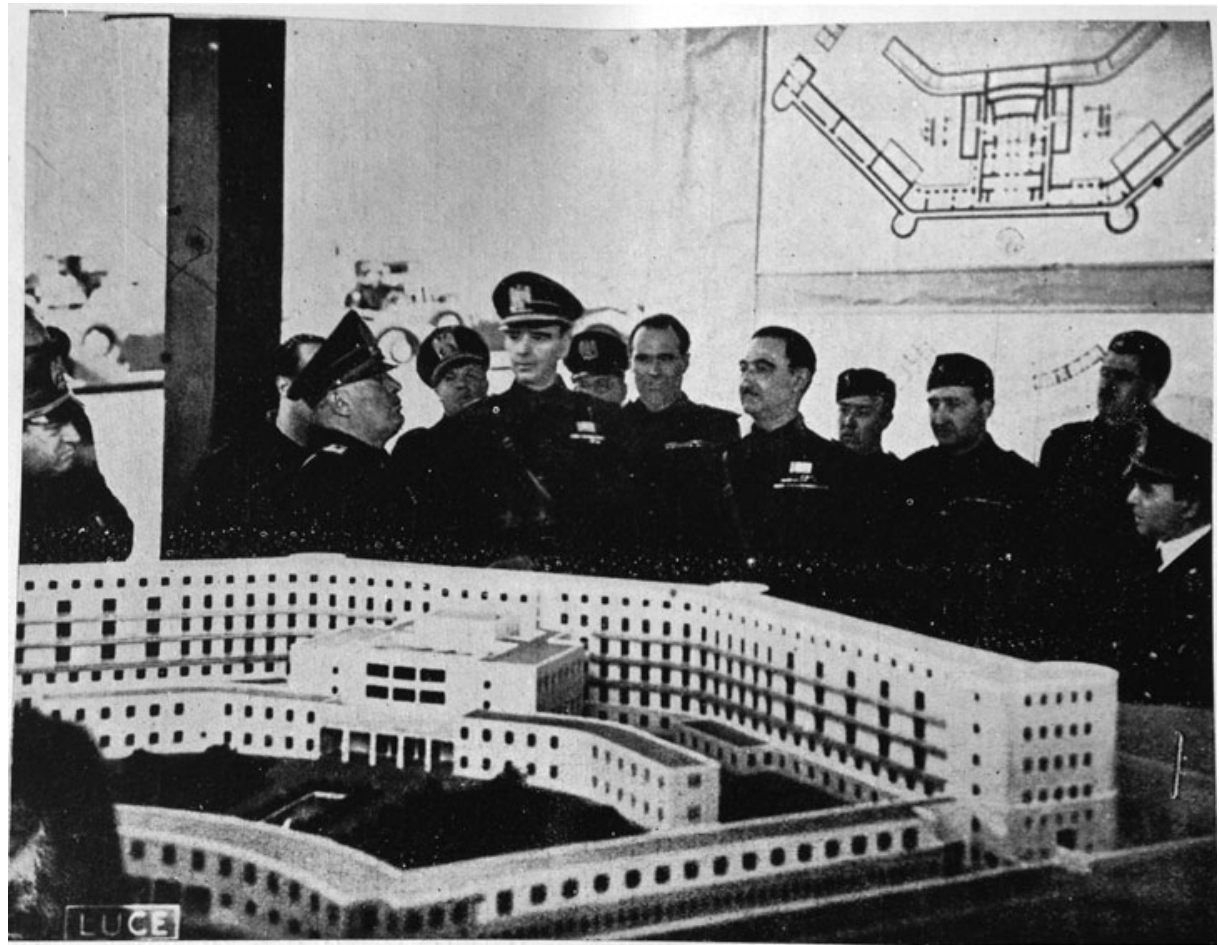

Figure 1. Mussolini and Pende with a scale model of the Biotypological Orthogenetic Institute in Rome, 1938. Sellina Gualco and Antonio Nardi, L'Istituto Biotipologico Ortogenetico di Roma, Rome: Tip. L. Proja, 1941.

in either Genoa or Rome were referred there by doctors. ${ }^{62}$ In their account of the activities at the institute in Genoa, Barbara and Vidoni were vague about the numbers undergoing treatment, referring only to 'thousands'. ${ }^{63}$ According to Gualco and Nardi, a plausible estimate might be that some 70,000 individuals were examined each year. ${ }^{64}$ If the institute had been open seven days a week, this means they must have examined around 190 individuals a day.

\section{The Biotypological Orthogenetic Institute as a sexological centre}

Only a month after Pende's institute had opened in Genoa, the journal Riforma medica (Medical Reform) stated that the institute offered 'sexual education', and that 'problems'

62 Anon., op. cit. (43), p. 75. Pende's clinical cases came from all over Italy. See, for example, Nicola Pende, Anomalie della crescenza fisica: Lavori dell'Istituto Biotipologico-Ortogenetico di Genova, vol. 2, Bologna: Licinio Cappelli Editore 1929, pp. 69-277.

63 Barbara and Vidoni, op. cit. (46), p. 21. On Vidoni's role in criminal anthropology see Mary Gibson, Born to Crime: Cesare Lombroso and the Origins of Biological Criminology, Westport, CT: Praeger, 2002, pp. 217-223.

64 Gualco and Nardi, op. cit. (23), p. 11. 
such as 'prostitution, homosexuality, sterility' could be avoided with an early 'correction' of the endocrine glands, a facility that was offered through various hormone therapies. ${ }^{65}$ Riforma medica was not the only journal or documentary source to draw attention to the fact that the institute routinely applied itself to the 'correction' of sexual anomalies. Among other things, Barbara and Vidoni said, with reference to the institute in Genoa, the Biotypological Orthogenetic Institute had set out to 'correct' 'organic hereditary weaknesses', to rectify 'sexual anomalies' and to forestall 'moral deviations', especially in adolescents. ${ }^{66}$

Clearly, the Biotypological Orthogenetic Institute came to function as a sexological centre. Not only did it offer sex education, as the Riforma medica had observed, it also provided premarital counselling, evaluating racial unions and favouring those that would, it reckoned, produce 'fit' offspring in the long term. Moreover, medical researchers working at the institute studied human sexual differences, assessing which constitutions were likely to prove more fertile, and how to increase the level of fecundity in women and sexual potency in men. They put such studies into practice, and by employing hormone treatments they treated infertility, and so-called 'sexual anomalies' and sexual dysfunctions such as impotence. They also conducted experimental research into the functioning of the sexual glands, and manipulated the secondary sexual characteristics if they were ambiguous. The Biotypological Orthogenetic Institute's aim to maximize the fertility of men and women, and to normalize them sexually, was consistent with the Fascist regime's ambition to renew the 'Italian stock' and create a 'New Man'. ${ }^{67}$ In the 1939 introduction to Pende's book Scienza dell'ortogenesi, the editors from the minor publishing house Istituto Italiano d'Arti Grafiche Editore wrote that Italy's future might depend on productive and reproductive Italians. The actual strength of the country relied, they declared, on its capacity to 'normalize' Italians, and Pende's orthogenetic biotypology was a tool to achieve such 'normalization'. ${ }^{68}$ This suggests that, first, those in scientific circles were aware that the control and management of citizens' bodies and sexuality were of critical importance to the Fascist regime. Second, it suggests that they consciously valued and pursued normalization in the sexual sphere. Two years later, Gualco and Nardi were once again at some pains to highlight the importance to the institute of controlling and managing sexuality: 'to improve and

65 Anon., op. cit. (43) p. 75.

66 Barbara and Vidoni, op. cit. (46).

67 On the myth of the 'New Man' in Fascist Italy see Emilio Gentile, Fascismo: storia e interpretazioni, Rome: Laterza, 2005, pp. 235-264; on sexuality and the New Man see George L. Mosse, Nationalism and Sexuality: Respectability and Abnormal Sexuality in Modern Europe, New York: H. Fertig, 1985. As Lorenzo Benadusi has observed, when it came to men, both purposes also meant the masculinization of men and the suppression of homosexual behaviour. He has surveyed some of the hormone treatments available to endocrinologists and surgeons for the purported treatment of homosexuality in Europe, such as gland transplants, in the interwar period. However, while Benadusi has the merit of identifying the importance of endocrinology in Pende's work as a way to make men more masculine, he does not explore these same treatments in the context of Pende's institute or as administered by Pende himself. See Lorenzo Benadusi, The Enemy of the New Man: Homosexuality in Fascist Italy (tr. Suzanne Dingee and Jennifer Pudney), Madison: University of Wisconsin Press, 2012, pp. 50-57.

68 Editore, 'Introduzione', in Pende, Scienza dell'ortogenesi, op. cit. (34), p. 6. 
enhance the race we [the institute] propose the accurate control of the sexual development of the two sexes, and the biological, hygienic and, should the need arise, the medical modification of the reproductive system before marriage'.69 At the Biotypological Orthogenetic Institute, control of the body and sexuality is attested by the systematic examinations performed by researchers and by the innumerable files they compiled, while management is illustrated through the active normalization of Italians using hormone therapies. The rest of this article will examine these two aspects. The methodical recording of the individual's bodily characteristics, their hormonal constitution, and endocrinological functions and dysfunctions thus illustrates the extent to which Pende's institute efficiently and systematically attempted to control Italians, while the hormone therapies administered at the institute reflect the invasive aspect of Italian eugenics.

\section{The biotypological orthogenetic file}

A core activity of the institute was the biotypological orthogenetic file (cartella biotipologica ortogenetica) or 'biotypological card', a document developed by Pende, which eugenicists in Argentina, Brazil and Mexico adopted in the 1930s. ${ }^{70}$ This card collected information about the individual's health, morphology, psychology and general behaviour and was a personal notebook that doctors had to complete, ideally every six months, prior to the individual becoming an adult, and subsequently less frequently. It contained information about the individual's genealogy-for example, whether parents and close relatives had suffered from hereditary diseases or anomalies. It also collected notes on behaviours that might appear eccentric or unusual, and even dietary habits. The card identified which biotype each individual belonged to and recorded a long list of measurements such as height, weight and the size of the thorax. There was also information about the functioning of various organs, such as the heart and lungs, and the operation of the endocrine glands, checked through medical tests. Finally, this biotypological card also included information about the intellectual and moral sphere, and the psychological attitudes of each individual.

A telling example of a control technique characteristic of Foucault's concept of governmentality, the biotypological card had been devised with the ultimate aim of managing and optimizing the entire Italian population. ${ }^{71}$ Indeed, in creating the biotypological card, Pende foresaw a time when all Italians would have one. Their

69 Gualco and Nardi, op. cit. (23), p. 157.

70 On Latin America see Andrés H. Reggiani, 'Depopulation, fascism, and eugenics in 1930s Argentina', Hispanic American Historical Review (2010) 90(2), pp. 283-318. According to Mantovani, Lombroso developed a 'biographical card' that can be considered the forerunner of Pende's biotypological orthogenetic file. Lombroso's biographical card was used in schools and police archives. See Mantovani, op. cit. (3), pp. 228-229. On the connection between Italy and Argentina see Chiara Beccalossi, 'Latin eugenics and sexual knowledge in Italy, Spain and Argentina: international networks across the Atlantic, 1916-46' in Douglas Haynes, Veronika Fuechtner and Ryan Jones (eds.), A Global History of Sexual Science, 18801960, Oakland: University of California Press, 2017, pp. 304-329.

71 Michel Foucault, The Birth of Biopolitics: Lectures at the Collège de France 1978-1979, Basingstoke: Palgrave Macmillan, 2008 (first published 2004). 
biopsychical state could thereby be monitored and symptoms of deviance within the individual identified and promptly adjusted. Initially created for those who were examined at the Biotypological Orthogenetic Institute in Genoa, the biotypological card became adopted on a nationwide basis in less than ten years, the key element being an impressive monitoring and control system.

Pende was able to take the biotypological card beyond his institute's walls thanks to his involvement with the ONB and his scientific prestige and intellectual influence in the medical world. The ONB was created in 1926 to mould the 'New Man' through leisure activities, in particular sport, and it also functioned as a paramilitary organization for children and young people between the ages of eight and eighteen. ${ }^{72}$ In the course of the following decade it grew enormously and became a youth mass organization that, by 1937 , could boast of having 5,693,665 members. Among other things, thanks to the membership fee, it provided medical assistance for its young members. ${ }^{73}$ When it was founded, the Ministry of Interior instructed the various regional institutions that provided healthcare to create clinics in each ONB headquarters. Thus ONB clinics were soon set up to provide a basic medical examination, some specialist examinations such as eye tests, and information about contagious diseases. These clinics also administered preventive medicine to counteract the spread of those endemic diseases that afflicted Italians, tuberculosis and malaria among them. ${ }^{74}$ The Ministry of Interior initially helped to fund these clinics, but the local healthcare system was responsible for maintaining them in the longer term. In 1931, 235 clinics were already open; by 1934 there were 4,200 ONB clinics in Italy. ${ }^{75}$ By the beginning of 1930 some medical doctors had enrolled in the National Fascist Party (PNF) and by 1931 there were already 3,067 ONB doctors. ${ }^{76}$ They published in journals such as Rivista di scienze applicate all'educazione fisica e giovanile (Journal of Applied Sciences to Physical and Youth Education) and held regular conferences. ${ }^{77}$ As I mentioned above, in 1928 Pende became director of the Fascist youth organization ONB for the Liguria region. Preventive medicine and hygiene were an integral part of Pende's biotypology as they also were of the ONB, and he probably thought that working for the ONB could help to extend biotypology to much of the general population. In this regard he was not mistaken. In 1930 Pende took part in the first national conference for ONB doctors and

72 Balilla (boys) and Piccole Italiane (girls) from eight to fourteen years old, Avanguardisti and Giovani Italiane from fourteen to eighteen years old. On the ONB see Alessio Ponzio, La palestra del Littorio. L'Accademia della Farnesina: un esperimento di pedagogia totalitaria nell'Italia fascista, Milan: Franco Angeli, 2009.

73 Ornella Stevallato, 'Gioventù fascista: l'Opera Nazionale Balilla', PhD thesis, 2008, p. 276.

74 Stevallato, op. cit. (73), p. 292.

75 Anon., 'L'attività sanitaria dell'Opera Balilla nell'anno XII nella relazione di S.E. Ricci al raduno dei dirigenti sanitari dei comitati provinciali', Rivista di scienze applicate all'educazione fisica e giovanile (1934) 5(6), pp. 303-312, 304.

76 Pende refers to 'more than three thousand doctors'. See Nicola Pende, 'Il controllo ortogenetico degli adolescenti organizzati dall'ONB', Rivista di scienze applicate all'educazione fisica e giovanile (1932) 3(4), pp. 247-259, 247. Stevellato, op. cit. (73), p. 271, who bases her estimate on the ONB annual report, has 3,067 doctors. On 27 May 1933, party membership was declared a basic requirement for public office.

77 Stevallato, op. cit. (73), pp. 270-290. 
recommended that all those working within the ONB should adopt the biotypological card. This proposal to use the card nationwide was taken up that same year, and from 1930 onwards all ONB members were in fact obliged to have a biotypological card, and therefore had to be examined according to the criteria of Pende's biotypology. In 1932, 732,000 Balilla members already had a biotypological card and had been examined. ${ }^{78}$ At the 1932 conference of the ONB doctors, Pende recommended that the ONB clinics should offer preventive medicine based on biotypology. His suggestion was once again accepted, and in 1934 the ONB clinics became ONB orthogenetic biotypological clinics. ${ }^{79}$ Pervasive control of the health of young Italians was taken even further when, in 1936, the biotypological card was finally introduced in all Italian schools. ${ }^{80}$

Through this expanding control system, until 1935 those individuals who had endocrine dysfunctions and presented (sexual) 'anomalies' that could be 'corrected' might routinely be referred to the Biotypological Orthogenetic Institute in Genoa, and after that date to the Rome institute. However, many men and women went to Pende's institute of their own accord: some brought their children to be examined and to seek career advice, as the institute also had an occupational medicine department, while others spontaneously sought treatment for their sexual dysfunctions and endocrinological problems. ${ }^{81}$ A study on surgical transplantations of multiple endocrine glands published by Pende in 1928, just two years after the opening of the institute in Genoa, shows that his endocrinological treatments were famous throughout Europe. Middle-class and professional men were especially inclined to seek a cure in Genoa, sometimes after attending other medical centres in Europe. ${ }^{82}$

The biotypological card gives us some sense of what it was that doctors were trained to observe: the size of the genitals, the development of secondary sexual characteristics, and even 'anomalies' of the sexual instinct were all recorded. ${ }^{83}$ Doctors were expected to comment on the 'development of the sexual organs'; the 'instinctual, emotional, volitional and intellective manifestations'; and 'the functional endocrine temperament' from the age of three upwards. ${ }^{84}$ These measurements were informed by biotypological studies. For example, Pende had published a number of guidelines about the size of 'normal' genitals in young people, from the age of seven to seventeen, and doctors had to check whether each individual matched these sizes. ${ }^{85}$ Pende put forward an idealized norm of the size of genitals: he did not supply any references to scientific studies of anthropometric or statistical averages of the size of Italians' (or any other population's) genitals. Doctors also had to conduct psychological investigations. For instance, at the

78 Pende, op. cit. (76), p. 250.

79 Anon., op. cit. (75), p. 305; Pende, op. cit. (76), p. 250; Stevallato, op. cit. (73), pp. 290-291.

80 The biotypological card was introduced in 1936 for all males between age eleven and military service. See Ipsen, op. cit. (3), p. 187; Mantovani, op. cit. (3), p. 322.

81 Nicola Pende, 'Impianti plurighiandolari eteroplastici nell'uomo per la cura delle endocrinopatie', Rassegna clinico-scientifica dell'Istituto Biochimico Italiano (15 August 1928) 6(8), pp. 339-346.

82 Pende, op. cit. (81), pp. 339-346.

83 Gualco and Nardi, op. cit. (23), pp. 197-198.

84 Pende, Scienza dell'ortogenesi, op. cit. (34).

85 Pende, Scienza dell'ortogenesi, op. cit. (34), Table XII. 
age of four children were asked whether they were (or identified as) male or female. ${ }^{86}$ Children's parents were questioned about their children's sexual instinct; for example, if they had noticed whether their sons and daughters were attracted to the opposite sex, whether their children welcomed caresses from other children, and whether they were curious about sexual matters. ${ }^{87}$ Pende recommended that doctors pay particular attention to the individual's sexual anomalies between the ages of eleven and thirteen because it was during this phase that they usually first appeared. ${ }^{88}$

Pende's biotypology provided a taxonomy enabling other doctors to read and codify human bodies, interpret the signs of anomalies, and identify personalities and behaviours. Using the biotypological card, anomalies were scrupulously recorded from early childhood, while anomalous bodies had to be 'normalized' as soon as possible. In his book Scienza dell'ortogenesi (1939), which also reproduces a biotypological card, Pende explained the main features of the nine fundamental endocrine temperaments. For example, the temperament dominated by the hyperfunctioning thyroid was characterized by a thin body shape, a 'lively physiognomy', an abundance of body hair, an active imagination, an early appearance of the sexual instinct and a very active 'psychosexuality'. ${ }^{89}$ Those with a temperament dominated by the hyperfunctioning of the genitals had an elongated body shape, they were generally tall but had a long torso, and their secondary sexual characteristics were pronounced. Children with a temperament characterized by a deficiency in the functioning of the pituitary gland were readily recognizable as they had oily skin, and their nose, ears, mouth, hands and feet were all small. As young men they would have a small penis and testes, and fat and feminine thighs, and as adults they would have a childish personality. Women with this temperament had a childish face, lacked hair on their genitals, and had limited fertility or were infertile. The 'hyperthymic temperament' was probably the most 'deviant' of all. It was characterized by early development of the body during childhood and a pallid face. Men with this temperament had testes 'with a peculiar hardness to the touch', ${ }^{90}$ and women had some signs of 'intersexuality', typically with masculine body hair and a flat chest. Boys had feminine secondary sexual characteristics and sometimes presented gynaecomasty. Overall, people with this temperament had a sexual instinct without a 'precise direction', 'homosexual tendencies', dubious morality and a lack of will power. ${ }^{91}$

\section{Treatments at the Biotypological Orthogenetic Institute}

Researchers working at the Biotypological Orthogenetic Institute adopted a range of hormone treatments, from natural to invasive (including surgical interventions). These

86 Pende, Scienza dell'ortogenesi, op. cit. (34), p. 71.

87 Pende, Scienza dell'ortogenesi, op. cit. (34), p. 46.

88 Pende, Scienza dell'ortogenesi, op. cit. (34), p. 150.

89 Pende, Scienza dell'ortogenesi, op. cit. (34), Table XVI.

90 The original Italian says: 'testicolo con durezza speciale alla palpazione'. Pende, Scienza dell'ortogenesi, op. cit. (34), Table XVI.

91 Pende, Scienza dell'ortogenesi, op. cit. (34), Table XVI. 
therapies show how actively the institute pursued the optimization and normalization of Italians by eliminating 'constitutional inadequacies'. Researchers recommended or else administered a number of natural therapies such as sunlight, mountain air and mineral water, and provided guidance for special diets. Individual diets, for example, were suggested according to the temperament each individual displayed. These remedies were designed to stimulate the natural production of hormones in men and women.

Medical researchers also offered a range of different radiation therapies, such as ultraviolet radiation therapy, X-ray therapy, phototherapy and Marconi therapy; that is, exposure to electromagnetic waves. These therapies were offered to stimulate the production of hormones, to treat some endocrinological dysfunctions, and allegedly to improve the individual's constitution. ${ }^{92}$ For example, at the institute in Rome, there was a room informally called the 'beach room', where children in particular were exposed to ultraviolet light therapy with the aim of stimulating hormone production. ${ }^{93}$ This therapy was especially employed to help those children with bodies that were smaller than normal for their age to grow and attain an average body size.

Some of the radiation therapies were used to 'correct sexual anomalies'. For instance, researchers believed that cryptorchidism, the condition in which one or both testes fail to descend from the abdomen into the scrotum, could be treated through the application of (unspecified) 'radiation' to the thymus gland. ${ }^{94}$ Gualco and Nardi explained that boys affected by cryptorchidism had a body fat distribution typically similar to that of girls, and that they had 'sexual, somatic and psychic anomalies' that could be treated though 'radiation' therapy of the thymus gland so that their sexual characteristics might develop in accordance with their own sex, and their intelligence be boosted. 95

At the institute, medical researchers also offered a range of endocrinological therapies such as opotherapy and glandular implants. These were used to treat infertility in men and women and impotence in men, and to normalize individuals who presented ambiguous genitals and/or secondary sexual characteristics. Gualco and Nardi explained that hormone therapies of different kinds could be administered at the Biotypological Orthogenetic Institute because its researchers were able to produce a wide range of opotherapy preparations and owned patented products manufactured by national and international pharmaceutical companies. ${ }^{96}$ Between the end of the 1920 s and the beginning of the 1940s, the institute deployed opotherapy with extracts based on testes or ovaries extracted from pigs, bulls, calves and other animals to treat individuals with ambiguous secondary sexual characteristics. ${ }^{97}$ In these years, according to Pende, the best way to administer opotherapy based on testicular extracts was orally through pills made of bull's testes, three or four times a day, or to administer the extracts intravenously. ${ }^{98}$

92 Gualco and Nardi, op. cit. (23), pp. 147-148.

93 Gualco and Nardi, op. cit. (23), pp. 146-147.

94 Gualco and Nardi, op. cit. (23), p. 158.

95 Gualco and Nardi, op. cit. (23), pp. 158-159.

96 Gualco and Nardi, op. cit. (23), p. 146.

97 See the various cases in Pende, op. cit. (62).

98 Nicola Pende, Terapia medica speciale, Milan: A. Wassermann \& C., 1932, p. 37. 
Some of the books written by Pende, such as Scienza dell'ortogenesi, present a number of cases of young men and women with various sexual anomalies that were treated with different kinds of opotherapy. As mentioned above, researchers at the Biotypological Orthogenetic Institute normalized ambiguous secondary sexual characteristics. This meant that they focused on and administered opotherapy to individuals who presented secondary sexual characteristics typical of the opposite sex, such as men 'suffering' from 'feminilism', women suffering from 'virilism' and both men and women suffering from 'eunuchism'. Pende even discussed opotherapy as a treatment for homosexuality and masturbation. ${ }^{99}$ Once the treatment for ambiguous sexual characteristics began, changes in the patients' genitals, body hair distribution and body fat distribution were recorded over a period of months or years. Photographs testified to the patients' normalization over long stretches of time and accompanied clinical cases published by the institute's researchers. Pende admitted that the treatment of 'feminilism' in men and 'virilism' in women, conditions grouped under the umbrella term of 'intersexuality', was not easily achieved. His clinical experience had shown that opotherapy based on ovary extracts in particular was not as successful in cases of 'virilism' in women - a condition that, according to Pende, might be associated with homosexuality - as in cases of men 'suffering' from 'feminilism'. He believed that the removal of the ovary, and, when possible, an ovary implant, were 'probably' more effective. ${ }^{100}$ In cases of 'feminilism' in men, Pende recommended the pluriglandular implanting of monkeys' testes and pituitary and thymus glands. ${ }^{101}$ Ideally, it was better to treat a man suffering from 'eunuchoidism' before the age of fourteen. As Pende explained, eunuchoidism was a difficult condition to treat, but therapies did exist and were administered. Therapies varied during the course of the history of the institute, depending on the technological innovations available, and eventually, in the 1940s, synthetic hormones replaced opotherapy. In the 1949 edition of Endocrinology, Pende said that the therapy for a man suffering from 'eunuchoidism' consisted of the daily injection of between 'one hundred and five hundred UR of gonadostimolina', a pharmaceutical product serving to 'stimulate' the gonads. This treatment went hand in hand with administering five to ten 'mrg of synthetic testosterone' every three or four days. ${ }^{102}$

Gualco and Nardi recounted that most of those attending the institute were given the appropriate hormone therapy and left on the same day, but for the more severe cases there was a surgical department where mono- and heteroplastic pluriglandular implants could be carried out. ${ }^{103}$ Pende extolled these implants as the optimal solution for a number of conditions. By 1932, Pende's clinical experience had revealed that in cases of 'genital' problems such as 'eunuchoidism', opotherapy was not overly effective. As with 'virilism' and 'feminilism', testis or ovary implants were likewise more successful for 'eunuchoidism'. Pende commented that human implants were the most effective,

99 Pende, Scienza dell'ortogenesi, op. cit. (34), pp. 234-235.

100 Pende, op. cit. (98), p. 39.

101 Pende, op. cit. (98), pp. 39-40.

102 Nicola Pende and Lorenzo Antognetti, Endocrinologia patologia e clinica degli orani a secrezione interna, 2 vols., Milan: Società editrice libraria, 1949, vol. 2, pp. 577-578.

103 Gualco and Nardi, op. cit. (23), pp. 145-146. 
although, he admitted, they were rarely possible; he therefore recommended the implanting of monkeys' glands. This did not imply transplanting only one gland, but multiple endocrine glands in the course of a single operation. This kind of treatment, the socalled heteroplastic pluriglandular implant, was favoured by Pende above all.104 Pende himself supervised heteroplastic pluriglandular implants at his institute, and used them for a number of conditions, including impotence and infertility.

In 1928 he published an article entitled 'Heteroplastic pluriglandular implants in man for the treatment of endocrinopathies' in the Rassegna clinico-scientifica dell'Istituto Biochimico Italiano (Clinical-Scientific Survey of the Italian Biochemical Institute), which offers an account of some of the uses of this technique. ${ }^{105}$ This article reported the results of two years of surgical transplantations of multiple endocrine glands, conducted since the opening of his Biotypological Orthogenetic Institute in Genoa. It focuses on twenty-one clinical cases of transplants of endocrine glands from monkeys to men and women carried out by the surgeon, Professor Luigi Durante, who was also working in Genoa at the time, and under the supervision of Pende himself. Most of the twenty-one patients were men treated for sexual impotence, lack of 'genital sensitivity' or problems with gaining an erection. There was also a woman who had been castrated, into whom Pende transplanted an ovary. Pende followed the patients' progress over the course of a few years and reported that the multiple transplants of glands such as testes and thyroid and pituitary glands (among others) were effective and that most of his male patients recovered their virility, meaning that their bodies had become more masculine and that they were finally able to have 'normal' erections. ${ }^{106}$

These operations were more than a little invasive. In his 1928 article, Pende explained the procedure involved in performing the heteroplastic pluriglandular implants. The implants entailed the use of fresh endocrine animal glands, especially from calves slaughtered shortly before the operation. The endocrine glands were removed from the animals while they were still alive; this operation had to be performed as swiftly as possible, and surgeons had to ensure the animals were in good health. The glands were then transplanted to both sides of the testicular tissue, and, for women, into the deep tissue of their breasts. ${ }^{107}$ The heteroplastic pluriglandular implants did not put down roots in the new body but, according to Pende, when inserted under the appropriate conditions, entered into a state of 'diminished life' (vita ridotta) for at least a year, or indeed, according to other famous endocrinologists such as Voronoff, for three or even four years. So the transplants continued to have endocrinal functions. ${ }^{108}$ Patients generally had a fever twelve or fourteen hours after the operation, which reached thirty-nine degrees for two or three days, with other symptoms including vomiting, hypotension and migraine. ${ }^{109}$

104 Pende, op. cit. (98), pp. 36-38.

105 Pende, op. cit. (81). I have analysed this study in more detail elsewhere; see Chiara Beccalossi, 'Italian sexology, Nicola Pende's biotypology and hormone treatments in the 1920s', Histoire, médecine et santé (2017) 12, pp. 73-98.

106 Pende, op. cit. (81).

107 Pende, op. cit. (81), p. 343.

108 Pende, op. cit. (81), p. 345.

109 Pende, op. cit. (81), p. 344. 
Most of the mono- and heteroplastic pluriglandular implants were followed by opotherapy extracts administered intravenously. ${ }^{110}$ In the first three to four months following the operation sexual performance might deteriorate, but it would eventually improve and be normalized. ${ }^{111}$

\section{Conclusion}

Biotypology is now discredited by scientists and yet it was a branch of medicine that in the interwar period and beyond had followers both within Italy and outside its borders. The French Société de biotypologie was established in 1932 and in the same year it launched Biotypologie, a journal that was still being published in the early 1960s. Latin America witnessed the founding of institutions that took Pende's Biotypological Orthogenetic Institute as a model, perhaps the most important of which was the Argentinian Istituto de Biotipología, Eugenesia y Medicina Social (Institute of Biotypology, Eugenics and Social Medicine) founded in Buenos Aires in $1931 .{ }^{112}$ In the US there were scientists who evidently fell under the spell of Pende's biotypology. For example, biotypology was the inspiration behind the psychologist William H. Sheldon's grand 'somatotyping project' of the 1940s and 1950s. ${ }^{113}$ Even today some basic assumptions of biotypology continue to circulate within popular culture. Health, nutrition, fitness and bodybuilding cultures highly value the role of hormones, and associate various bodily shapes, such as apple, pear, rectangle, triangle, round and so on, with specific physical and mental health types and even with personality.

In Italy, biotypology reached its peak under Italian Fascism, and the association between Fascism and biotypology is incontrovertible. It is difficult to assess exactly how many Italians were 'normalized' through the Biotypological Orthogenetic Institute, and the precise numbers treated will perhaps never be known. Historians have failed to unearth the clinical data registry of the Biotypological Orthogenetic Institute in Genoa and Rome. What we do have are the estimates given by Gualco and Nardi mentioned above. Yet by the first half of the 1930s, the establishment of the ONB orthogenetic clinics in major Italian cities and the introduction of biotypological cards in schools had initiated a pervasive referral system. It became much easier to identify individuals who were not deemed fit enough and to refer them to the Biotypological Orthogenetic Institute. Supported by the Fascist regime, biotypologists

110 Gualco and Nardi, op. cit. (23), p. 146.

111 Pende, op. cit. (81), p. 345.

112 Rossi Arturo, Tratado teorico pratico de Biotipologia y ortogenesis, vol. 1, Buenos Aires: Editorial Ideas, 1944, p. 39. For the influence of Pende in Latin America see Stepan, op. cit. (10); Reggiani, op. cit. (70), pp. 283-318; Marisa Miranda, Controlar lo incontrolable: Una historia de la sexualidad en la Argentina, Buenos Aires: Biblos, 2011; Luis Ferla, 'El determinismo biotipológico y su red de sustentacióna través de eugenistas espanõles, brasileños y argenitinos', in Marisa Miranda and Gustavo Vallejo (eds.), Una historia de la engenesia: Argentina y las redes biopoliticas internationals (1912-1945), Buenos Aires: Biblos, 2012; Ana Carolina Vimieiro Gomes, 'Science, constitutional medicine and national bodily identity in Brazilian biotypology during the 1930s', Social History of Medicine (2017) 30(1), pp. 137-157; Beccalossi, op. cit. (70).

113 Quine, op. cit. (11), p. 113. 
managed to set up a widespread control system. Hormone treatments were employed on a daily basis and this was done with the explicit aim of optimizing and normalizing Italians in line with the Fascist ideal of creating the 'New Man'.

The Biotypological Orthogenetic Institute was not unique in Italy as regards its eugenic purposes. Indeed, the destruction wrought during the First World War and the attendant sense of national decline had led to the launch of a number of projects to renew the Italian stock, among them programmes to protect children and mothers, and the creation of enterprises such as OMNI. The real novelty of Pende's institute lay in its use of endocrinology, which came to offer highly practical tools of intervention, in the guise of hormone treatments, to improve the Italian stock. It is worth stressing that such tools took the form of postnatal interventions and, as such, were consistent with the fundamental tenets of the Catholic religion. Yet hormone treatments ranging from various forms of radiation therapy to pluriglandular implants were invasive medical procedures.

Pende's eugenics programme rested on the assumption that not only was the human body malleable, but so too were both primary and secondary sexual characteristics. He regarded the attributes of masculinity and femininity as amenable to deliberate engineering and manipulation. In order to make Italian men more virile and Italian women more fertile, he relied on the capacity of modern medicine to manipulate what we now call sex hormones. In this sense he put the study of sexual characteristics at the heart of his activities. Pende's institute was therefore also a sexological centre in which various hormone therapies, from opotherapy to gland transplants, inaugurated a new era of invasive treatments designed to significantly alter the individual's body, and thus to forge ideal types of men and women, each with their harmonious proportions and hormonal balances. Yet the 'normal' biotype described by Pende, with all primary and secondary sexual characteristics falling into parameters of a standardized normality, did not exist in reality. ${ }^{114}$ By modifying men and women towards an ideal sexual being, Pende's institute measured the differences by which individuals' sexual characteristics deviated from the norm. In doing so, it created taxonomies and differences, and demarcated male and female characteristics. While hormone therapies normalized men and women, the theories bequeathed by the endocrinologists of the interwar period have created a plethora of deviant types, such as men with penises that are too small, women with flat breasts, men and women with a lack of or excessive body hair, men with curvy hips, women with no curves at all, chubby men and skinny women. These theories glorified the virility of the 'New Man', the dynamic and muscular man, and the femininity of prolific mothers. They glorified the Fascist ideal man and the Fascist ideal woman.

114 On the problematic aspects of the concepts of normality in scientific discourses in the nineteenth and twentieth centuries, including the difficulty of finding normal values in living and individual bodies, see Cryle and Stephens, op. cit. (9). 